\title{
Syn-thrusting, near-surface flexural-slipping and stress deflection along folded sedimentary layers of the Sant Corneli-Bóixols anticline (Pyrenees, Spain)
}

\author{
Stefano Tavani ${ }^{1}$, Pablo Granado ${ }^{2,3}$, Pau Arbués ${ }^{2,3}$, Amerigo Corradetti ${ }^{1}$, and J. Anton Muñoz ${ }^{2,3}$ \\ ${ }^{1}$ DiSTAR, Università degli Studi di Napoli “Federico II”, Largo S. Marcellino 10, 80138 Naples, Italy \\ ${ }^{2}$ Institut de Recerca Geomodels, Universitat de Barcelona, Martí i Franquès s/n, 08028 Barcelona, Spain \\ ${ }^{3}$ Departament de Dinàmica de la Terra i de l'Oceà, Universitat de Barcelona, Martí i Franquès s/n, 08028 Barcelona, Spain
}

Correspondence to: Stefano Tavani (stefano.tavani@unina.it)

Received: 9 January 2017 - Discussion started: 17 January 2017

Revised: 3 March 2017 - Accepted: 10 March 2017 - Published: 4 April 2017

\begin{abstract}
In the Spanish Pyrenees, the Sant Corneli-Bóixols thrust-related anticline displays an outstandingly preserved growth strata sequence. These strata lie on top of a major unconformity exposed at the anticline's forelimb that divides and decouples a lower pre-folding unit from an upper syn-folding one. The former consists of steeply dipping to overturned strata with widespread bedding-parallel slip indicative of folding by flexural slip, whereas the syn-folding strata above define a $200 \mathrm{~m}$ amplitude fold. In the inner and outer sectors of the forelimb, both pre- and syn-folding strata are near vertical to overturned and the unconformity angle ranges from 10 to $30^{\circ}$. In the central portion of the forelimb, syn-folding layers are gently dipping, whereas the angular unconformity is about $90^{\circ}$ and the unconformity surface displays strong $\mathrm{S}-\mathrm{C}$ shear structures, which provide a top-toforeland slip sense. This sheared unconformity is offset by steeply dipping faults, which are at low angles to the underlying layers of the pre-folding unit. Strong shearing along the unconformity surface also occurred in the inner sector of the forelimb, with S-C structures providing an opposite, topto-hinterland slip sense. Cross-cutting relationships and slip senses along the pre-folding bedding surfaces and the unconformity indicate that regardless of its orientation, layering in the pre- and syn-folding sequences of the Sant CorneliBóixols anticline were continuously slipped. This slipping promoted an intense stress deflection, with the maximum component of the stress tensor remaining at low angles to bedding during most of the folding process.
\end{abstract}

\section{Introduction}

Templates used to describe the state of stress of growing regional-scale thrust-related anticlines (e.g. Hancock, 1985; Lisle, 1994; Fischer and Wilkerson, 2000; Belayneh and Cosgrove, 2004; Tavani et al., 2015) typically integrate punctual strain data (e.g. Engelder and Geiser, 1980; Laubach, 1989; Lacombe, 2012; Balsamo et al., 2016) and indirect information provided by the large-scale geometry of the structure, such as curvature or strata thinning or thickening (e.g. Price and Cosgrove, 1990). Widespread documentation of bedding-parallel slip and preservation of layer thickness provides key information for modelling the distribution of stress in actively growing anticlines. These observations indicate flexural-slip folding in the multilayered portions of reservoir-scale thrust-related folds (e.g. Donath and Parker, 1964; Ramsay, 1967; Tanner, 1989; Suppe, 1983; Fowler, 1996; Erslev and Mayborn, 1997). The assumption and/or observation of flexural slipping has important consequences for the stress distribution:

- Slipping along numerous bedding surfaces with a wide range of bedding dip is only possible where the bedding surfaces have a low friction and a low cohesion.

- Conversely, the reactivation of these closely spaced lowfriction surfaces should prevent the layer-parallel shear stress to exceed a certain value, which in turn constrains the direction of the maximum component of the stress field to be at low angle to bedding, i.e. at low angle to 
the slipping surface (Wiltschko et al., 1985; Ohlmacher and Aydin, 1997; Tavani et al., 2015).

The process of layer-parallel slipping is, however, discontinuous in time and space, making it unclear whether the regional stress only reorients locally or if the layer-parallel slipping is sufficiently dense, both in time and space, to promote the reorientation of the stress in wide, actively folding areas. Field data are in agreement with the second hypothesis, i.e. that slipping along low-friction bedding surfaces promotes deflection of the principal directions of the remote stress field, so that the direction of the maximum compressive stress maintains at low angle to the bedding; thus, the maximum stress in active fold and thrust belts may not always be strictly horizontal. In fact, syn-folding layerparallel shortening structures are reported in the folded pregrowth strata of many thrust-related anticlines (e.g. Tavani et al., 2006, 2012). However, palaeo-stress and/or palaeostrain indicators cannot easily and unequivocally constrain the range of bedding dip values at which such stress deflection mechanisms can operate (e.g. Callot et al., 2010; Beaudoin et al., 2012). In fact, almost all published datasets come from pre-growth sequences of thrust-related folds. In these cases, determining the bedding dip when a given set of deformation structures are formed (i.e. fractures or slickenlines along a bedding surface) remains difficult, and any assumptions made carry significant uncertainty.

Conversely, observations made in syn-growth layers of thrust-related anticlines serve to drastically reduce uncertainties related to the timing of deformation (e.g. Shackleton et al., 2005, 2011). In fact, the study of growth strata sequences are by far the most commonly used approach for understanding the kinematics of fault-related folds in contractional settings (e.g. Suppe et al., 1992, 1997; Burbank et al., 1996; Ford et al., 1997; Vergés et al., 2002). In contrast with the abundance of detailed geometrical studies (Suppe, 1983; Medwedeff, 1989; Mitra, 1990; Suppe and Medwedeff, 1990; Zapata and Allmendinger, 1996; Poblet et al., 1997; Suppe et al., 1997), only a few contributions dealing with the dynamics of folding inferred from syn-kinematic layers have been published (e.g. Ford et al., 1997; Nicol and Nathan, 2001; Shackleton et al., 2011), mostly because of the lack of well-preserved and accessible exposures. In this work we have focused on the macro- and meso-structures developed within a growth strata wedge and a related major synkinematic unconformity exposed at the forelimb of the Sant Corneli-Bóixols anticline. Bedding-parallel slip occurs along pre- and syn-kinematic strata, which are oriented obliquely to each other, together with mesoscale faults cutting across strata and the unconformity. Thus, this area provides an excellent, almost unique field example to observe, describe and analyse how oblique anisotropies, i.e. layers and unconformity, respond to progressive shortening and related folding in a contractional setting. In addition, the studied area allowed us to determine the threshold dip value at which flexural slip is of sufficient magnitude to deflect the maximum principal stress direction from the regional stress field.

\section{Geological setting}

The Pyrenean Belt is a doubly vergent orogenic wedge (Fig. 1a) formed during the Late Cretaceous to Miocene subduction of the Iberian lithosphere beneath the Eurasian plate (e.g. Choukroune et al., 1990; Muñoz, 1992; Teixell, 1998). It largely deformed and inverted the Mesozoic extensional basins developed between Iberia and Eurasia during the Mesozoic separation of these two plates (Muñoz, 2002). The Early Cretaceous Organyà basin developed on the thinned continental crust of the Iberian plate to the south of the exhumed mantle domain of the Pyrenean rift (e.g. Tugend et al., 2014). Upon convergence and shortening, the Organyà basin was positively inverted and incorporated into the hanging wall of the Bóixols thrust starting in Late Cretaceous times (e.g. Mencos et al., 2015 and references therein). The positive inversion of the inherited extensional structures occurred under oblique, NNW-SSE oriented convergence (Tavani et al., 2011) and was responsible for the development of the E-W-striking Sant Corneli-Bóixols anticline (Fig. 1a). The location and geometry of this anticline is controlled by the orientation of the Early Cretaceous extensional border fault system of the Organyà basin (e.g. Bond and McClay, 1995; García-Senz, 2002; Mencos et al., 2015).

Several detailed studies of the stratigraphy of the Organyà basin have been carried out in the last 50 years (e.g. Rosell, 1963; Garrido, 1973; Simó, 1986; Berástegui et al., 1990; García-Senz; 2002; Mencos, 2011). The pre-rift Mesozoic stratigraphy is represented by clays and evaporites belonging to the Triassic Keuper facies, followed by Jurassic shallow marine carbonates and deeper water marls. The Early Cretaceous syn-rift megasequence consists of platform carbonates that thicken towards the north and change laterally (i.e. toward the north) into basinal marls (e.g. GarcíaSenz, 2002). In the hanging wall of the Bóixols thrust, the maximum thickness of the syn-rift megasequence is about $4500 \mathrm{~m}$. It thins southwards around the hinge zone of the Sant Corneli-Bóixols anticline across the extensional fault system at the southern margin of the Organyà basin (Lanaja et al., 1987; Berástegui et al., 1990; Arbués et al., 1996; García-Senz, 2002; Muñoz et al., 2010; Mencos et al., 2015). The Upper Cenomanian to lower Santonian post-rift megasequence consists of carbonates with lesser clastics and can be up to $700 \mathrm{~m}$ thick (García-Senz, 2002; Mencos, 2011). The syn-orogenic strata are exposed in the leading syncline (i.e. Tremp-Sallent syncline) of the Sant Corneli-Bóixols anticline (Fig. 1a-b) and include more than $1000 \mathrm{~m}$ of Upper Santonian to Palaeocene deep water and continental strata that thin abruptly to a few tens of metres northwards, i.e. towards the Sant Corneli-Bóixols anticline (e.g. Arbués et al., 1996; Roma et al., 2011). 

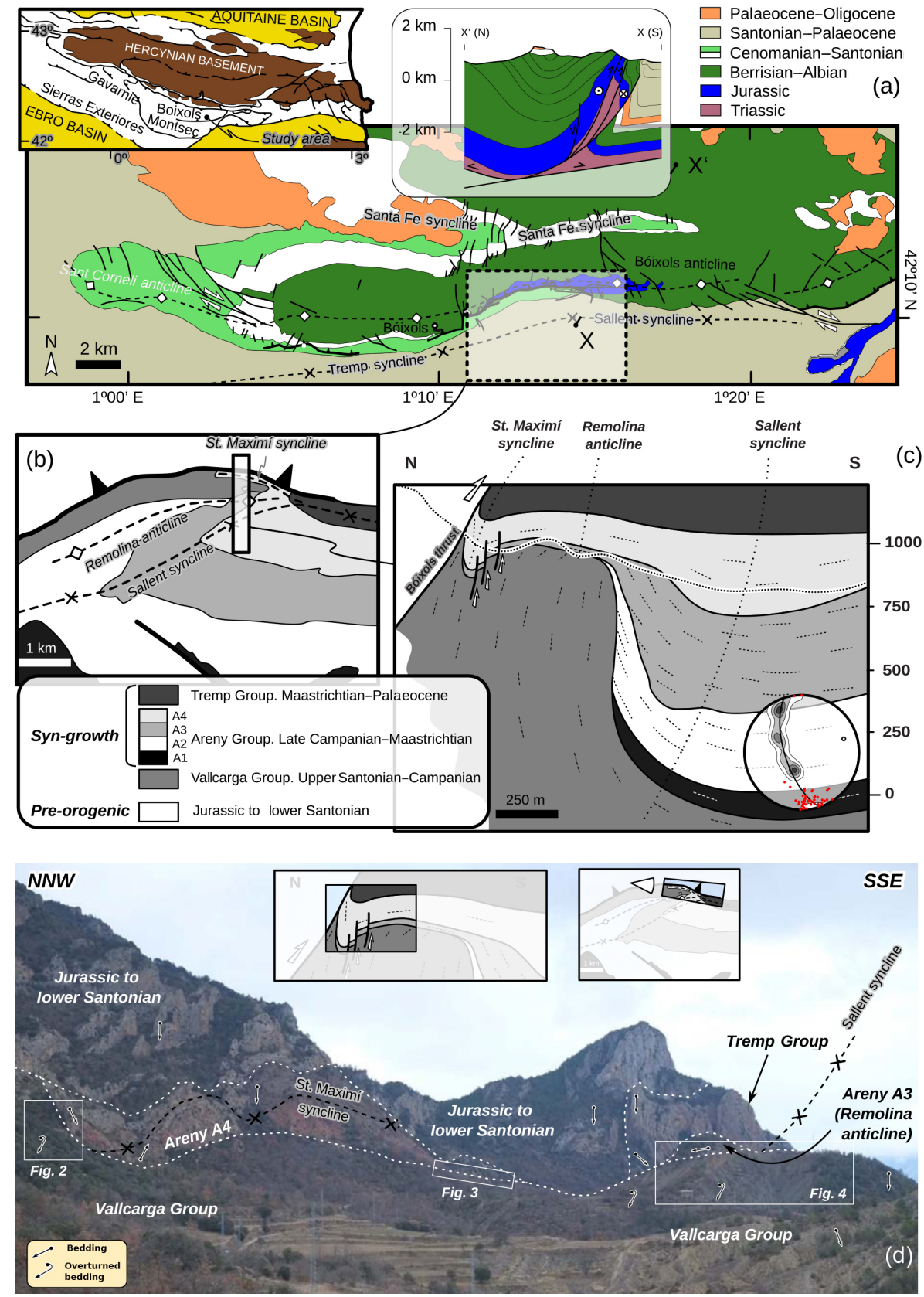

Figure 1. (a) Geological maps of the eastern Pyrenees, with detail and cross section (modified from García-Senz, 2002) of the Sant CorneliBóixols anticline. Geological map (b) and schematic cross section (c) of the study area, with cumulative contouring of poles to bedding and best-fit beta axis of syn-folding beds and poles of pre-folding beds (red circles). (d) Panoramic view of the study area, with insets showing the location of Figs. 2 to 4 and the photographed area in cross section and map view respectively.

In the studied area, the syn-orogenic succession can be subdivided into two units (Fig. 1b-c): (1) the lower, Upper Santonian to Campanian Vallcarga Group (Nagtegaal, 1972) is constituted by a multilayered marine sequence of thin to medium bedded limestones and mudstones. Around the Sant Corneli-Bóixols anticline, the Vallcarga Group was deposited during folding, as evidenced by growth geometries at the eastern tip of the Sant Corneli-Bóixols anticline (Men- cos et al., 2015). However, no clear indications of deposition during the early stages of folding are visible in the studied area and hence it is here geometrically considered as prefolding but within a regional syn-orogenic scenario. (2) The Late Campanian to Maastrichtian Areny Group (Arbués et al., 1996) unconformably overlies the Vallcarga Group. Its thickness exceeds $1000 \mathrm{~m}$ in the Tremp-Sallent syncline depocentre (Fig. 1a-b) but thins abruptly to a few tens of metres 
towards the Sant Corneli-Bóixols anticline; thus, it is considered to have been deposited during folding (i.e. syn-folding). The Areny Group records sedimentation in deep water and neritic conditions coeval with the inversion and related folding of the Organyà extensional basin. The Areny Group has been divided into four depositional sequences (A1 to A4 from older to younger; Arbués et al., 1996; Roma et al., 2011) that, overall, display a marked regressive character. The A1 depositional sequence includes deep-water olistostromes, deep-water mudstones, outer-shelf mudstones and calcarenites, and fan-deltaic conglomerates and sandstones. The A2 depositional sequence includes fan-deltaic conglomerates and sandstones, deep-water mudstones, and outer-shelf mudstones-calcarenites and also includes re-sedimented, rudist-bearing limestones in boulder-sized blocks. The A3 depositional sequence includes deep-water slump-deformed marls, outer-shelf mudstones-calcarenites, inner-shelf and near-shore calcarenites and sandstones, and in situ, rudist build ups. Depositional sequence A4 is constituted by fan-deltaic conglomerates and sandstones, lagoonal to alluvial mudstones and sandstones, and alluvial fanglomerates. (3) The syn-folding Maastrichtian to Palaeocene Tremp Group (Cuevas, 1992) includes continental facies associations, which are commonly referred to as the Garumnian facies (Cuevas, 1992). These consist of alluvial and colluvial conglomerates and breccias, passing southwards to alluvial plain and fluvial reddish sandstones and mudstones (e.g. Arbués et al., 1996; Roma et al., 2011).

From a structural point of view, the major structures in the studied area are the Bóixols thrust and related splays, the E-W trending Sant Corneli-Bóixols anticline and the associated Santa Fe syncline to the north and the TrempSallent syncline to the south (Fig. 1a). The main ramp of the Bóixols thrust crops out in the study area, whereas to the west and to the east it remains blind along most of the frontal limb of the Sant Corneli-Bóixols anticline. In its exposed sector, the Bóixols thrust has Triassic to Upper Cretaceous pre-growth rocks in its hanging wall and syn-orogenic and syn-folding strata in its footwall (Fig. 1c). A thin sheet of overturned post-rift limestones, mainly the upper Cenomanian ones, defines two thrusts. The lower thrust remains blind beneath the vertical beds of the Garumnian succession on the northern limb of the Tremp-Sallent syncline. Conversely, the upper thrust truncates the Garumnian beds. This upper one is the Bóixols thrust, and according to magnetostratigraphic and thermochronological studies it would have been reactivated during Palaeogene times (Beamud et al., 2011). The pre-folding beds of the Vallcarga Group in the footwall of the Bóixols thrust are folded into a syncline with overturned strata immediately below the thrust fault. These strata progressively acquire sub-horizontal attitudes in the TrempSallent syncline to the south (Fig. 1c). Conversely, the unconformably overlying Areny and Tremp groups display a series of folded structures, namely the Sant Maximí syncline and the Tremp-Sallent syncline, with the Remolina anticline in between. The two synclines disappear toward the east, where the two synclines join (Fig. 1b). The three folds display a significant eastward plunge (Roma et al., 2011) of $24^{\circ}$, with a $\mathrm{N} 72^{\circ}$ plunge direction, as derived by the direction normal to the best-fit plane of bedding data of the Areny Group (Fig. 1c). These poles to bedding are well clustered along a great circle, thus defining the axis of a cylindrical fold. This suggests that the plunge was acquired after the deposition of the syn-folding Areny Group. In addition, it is to be noted that poles to pre-folding bedding are clustered along the same great circle, indicating that the folding axis was parallel to the intersection between the pre-unconformity beds and the unconformity (Ramsay, 1967).

\section{Macro- and meso-structures}

In the following, we describe the structural assemblages occurring along and around the major unconformity dividing the Areny Group from the Vallcarga Group, i.e. the upper syn-folding from the lower pre-folding strata respectively (Fig. 1d). The macro- and meso-structures are described from north to south in three subsections, corresponding to the three limbs of the S-shaped fold that define the Sant Maximí syncline, the Remolina anticline and the Tremp-Sallent syncline (Fig. 1). We will present and discuss stereoplots of bedding attitude, fault orientations and kinematic indicators from faults. In these stereoplots the plane normal to the structural plunge is also displayed in order to ease the interpretation of the fault kinematics. For each stereoplot, we also show the two graphs resulting from the removal of plunge first and then of the residual bedding dip (Ramsay, 1967).

\subsection{Northern limb}

On the inner (northern) limb of the Sant Maximí syncline, the marls and limestones of the Vallcarga Group are overturned, while the unconformably overlying strata of the Areny Group are steeply south dipping to near vertical (Fig. 2). In the northern limb of the syncline, the strata of the Areny Group include siltstones, sandstones and conglomerates belonging to the A4 depositional sequence; the A1 to A3 depositional sequences are missing (Fig. 2a-b), either because they were never deposited there or because they were eroded before the deposition of the A4 sequence. Overturned bedding surfaces of the Vallcarga Group display evidence of slipping. Movements along bedding are mostly toward the NW, with normal sense of slip in the present overturned bedding orientation (Fig. 2b). Stereoplots show that slickenlines along bedding surfaces of the Vallcarga Group are mostly perpendicular to the local fold axis. The unconformity between the Vallcarga and the Areny groups has been reactivated as a thrust and displays an intense $\mathrm{S}-\mathrm{C}$ fabric that affects a few metres of the Vallcarga Group (Fig. 2c). Similar to other S-C tectonites developed in carbonates and at shallow depth (e.g. Tesei et 

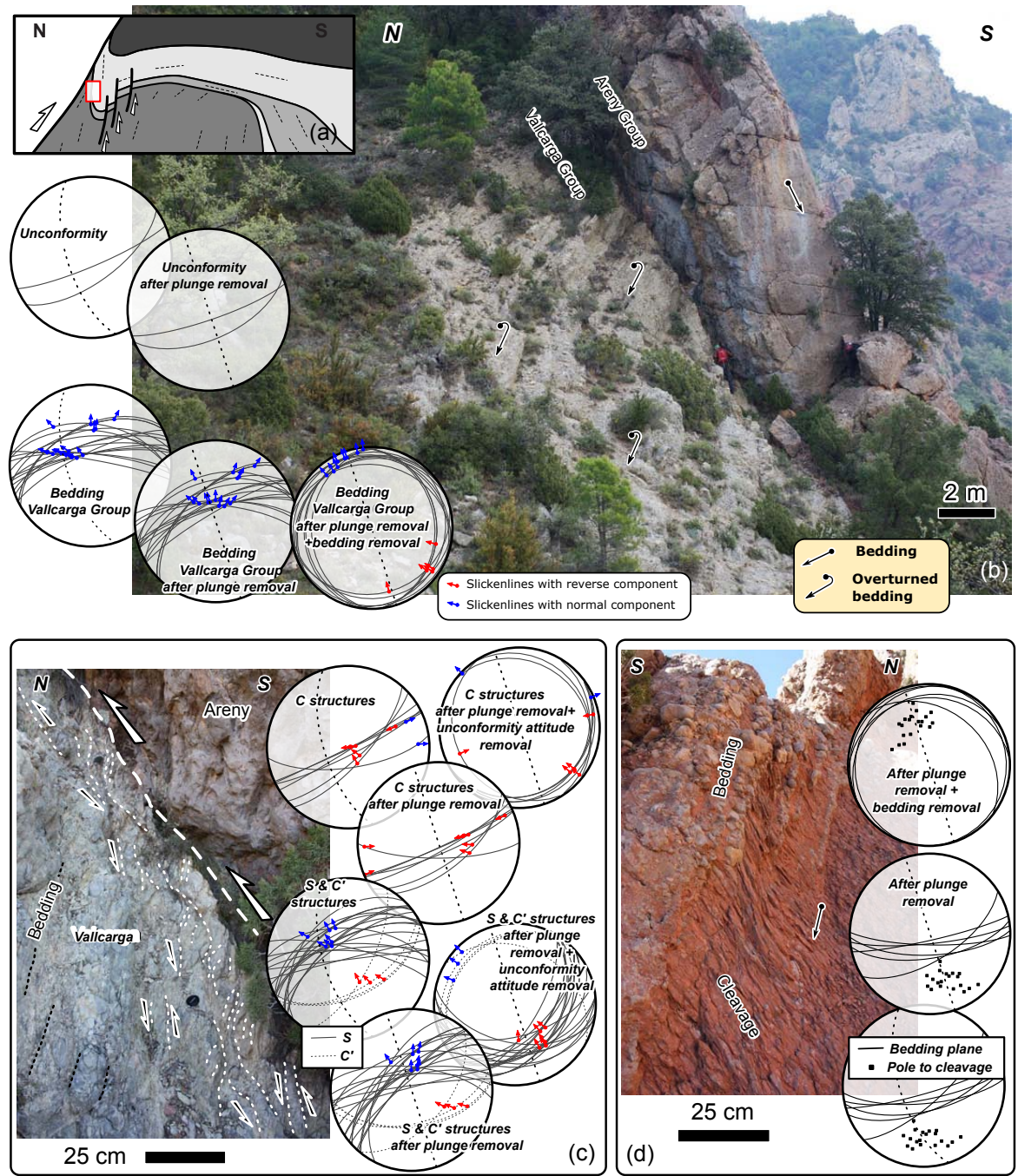

Figure 2. Structures exposed at the northern limb of the San Maximí syncline. (a) Cross-sectional location of the site. (b) South-dipping conglomerates of the Areny Group unconformably overlying the overturned north-dipping strata of the Vallcarga Group, with stereoplots of the unconformity and bedding surfaces in the Vallcarga Group. (c) Detail of the unconformity, showing S-C-C' fabric, with corresponding stereoplots. (d) South-dipping alternating conglomerates and siltstones of the Areny Group, with pervasive cleavage at high angle to bedding.

al., 2013; Vitale et al., 2014), the S-C structures found in the first $2-3 \mathrm{~m}$ of the Vallcarga Group immediately below the unconformity formed as a consequence of pressure solution of marly limestones and marls, thus indicating a ductile to brittle-ductile behaviour of the Vallcarga Group associated with this major fault. Slip directions provided by C, $\mathrm{S}$ and C' structures are top to NW and, comparable to the bedding-parallel slip surfaces, the average slip direction lies along the plunge-normal plane (Fig. 2c). The Areny Group conglomerates immediately above the unconformity are not affected by such $\mathrm{S}-\mathrm{C}$ fabric, whereas siltstones occurring a few metres above the unconformity are affected by a penetrative cleavage (Fig. 2d). This cleavage is at a high angle to bedding, as seen in the field and as evidenced by the fact that poles to cleavage in the stereoplot occur close to the bedding plane great circles (Fig. 2d). However, cleavage is not strictly bedding-perpendicular. Once bedding dip is restored to the horizontal, the poles to cleavage still lie along the plunge normal plane and cleavage becomes SE dipping. These relationships are indicative of a minor top-to-NW slip component during cleavage development. It is worth remarking that despite the importance for stress direction reconstruction, the cleavage described above is a localised feature, which affects only the silty beds of the uppermost portion of the Areny Group in some outcrops.

\subsection{Central limb}

Immediately to the south of the axial surface of the Sant Maximí syncline, strata of the Areny Group are shallow dip- 


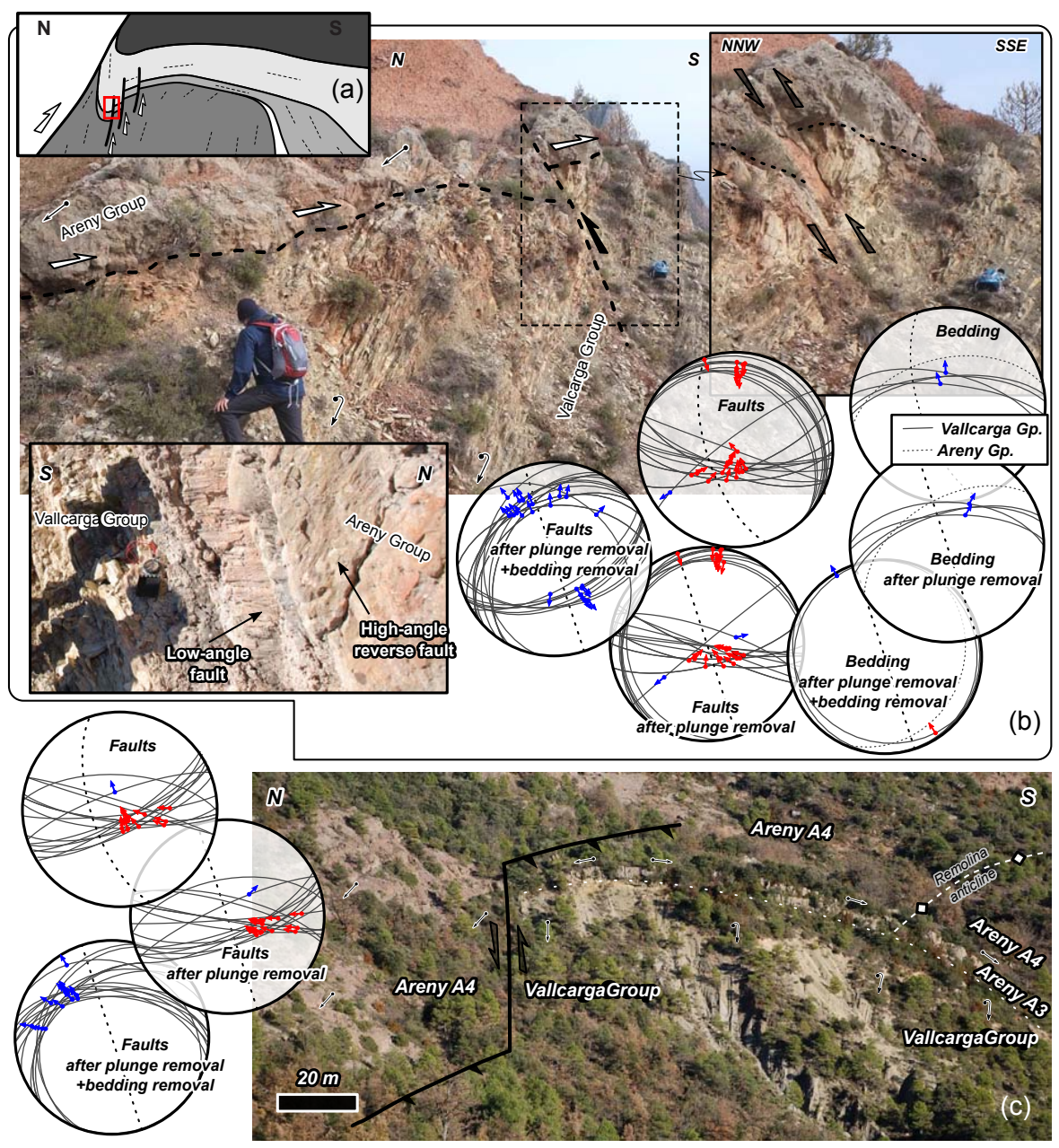

Figure 3. Transitional area between the San Maximí syncline and the Remolina anticline. (a) Cross-sectional location of the site. (b) Shallowdipping unconformity between the Areny and the Vallcarga groups reactivated as a low-angle fault and displaced by a high-angle fault. Details of the low- and high-dipping faults are shown, together with stereoplots of faults and bedding surfaces of the Vallcarga Group. (c) Panoramic view and stereoplot of a near-vertical fault system uplifting the Remolina anticline, which has folded strata of the Areny Group unconformably on top of near-vertical strata of the Vallcarga Group.

ping to sub-horizontal (Fig. 1c-d). Locally, however, strata of the A4 depositional sequence of the Areny Group are steeply north dipping and the Sant Maximí syncline forms a tight structure with a north-dipping to near-vertical axial surface. In the hinge zone, the unconformable strata of the Areny Group are separated from the underlying overturned strata of the Vallcarga Group by a sub-horizontal slip zone, which corresponds to the sheared syn-folding unconformity (Fig. 3). In addition, the sheared unconformity is offset by a series of high-angle faults that uplift the southern block (Fig. 3b). Striae along bedding surfaces of the Vallcarga Group indicate top-to-N movements with normal kinematics (Fig. 3b). Striae within the sub-horizontal slip zone indicate top-to-S movement, whereas the high-angle faults that offset it have slickenlines lying along the plunge-normal plane and show a top-to-N movement. A few strike-slip slickenlines also oc- cur along high-angle faults and are indicative of left-lateral movements. In other places, the system of high-angle reverse faults uplifting the southern limb of the Sant Maximí syncline displays a top-to-NW movement, including some rightlateral kinematic indicators (Fig. 3c). Looking at the system of high-angle faults in natural cross sections at a larger scale of observation (Fig. 3c), it is evident that these faults are approximately (i.e. angular difference is less than $10^{\circ}$ ) parallel to the bedding of the Vallcarga Group and that the amount of uplift of the southern block is a few tens of metres.

The uplifted southern block is well exposed at the Sallent hill (Fig. 4). There, the sub-horizontal rudist-bearing units of the A3 depositional sequence sit unconformable on top of the overturned north-dipping strata of the Vallcarga Group (Fig. 4a-b). Slickenlines are consistently found on bedding surfaces of these strata. As shown in the stereoplots 

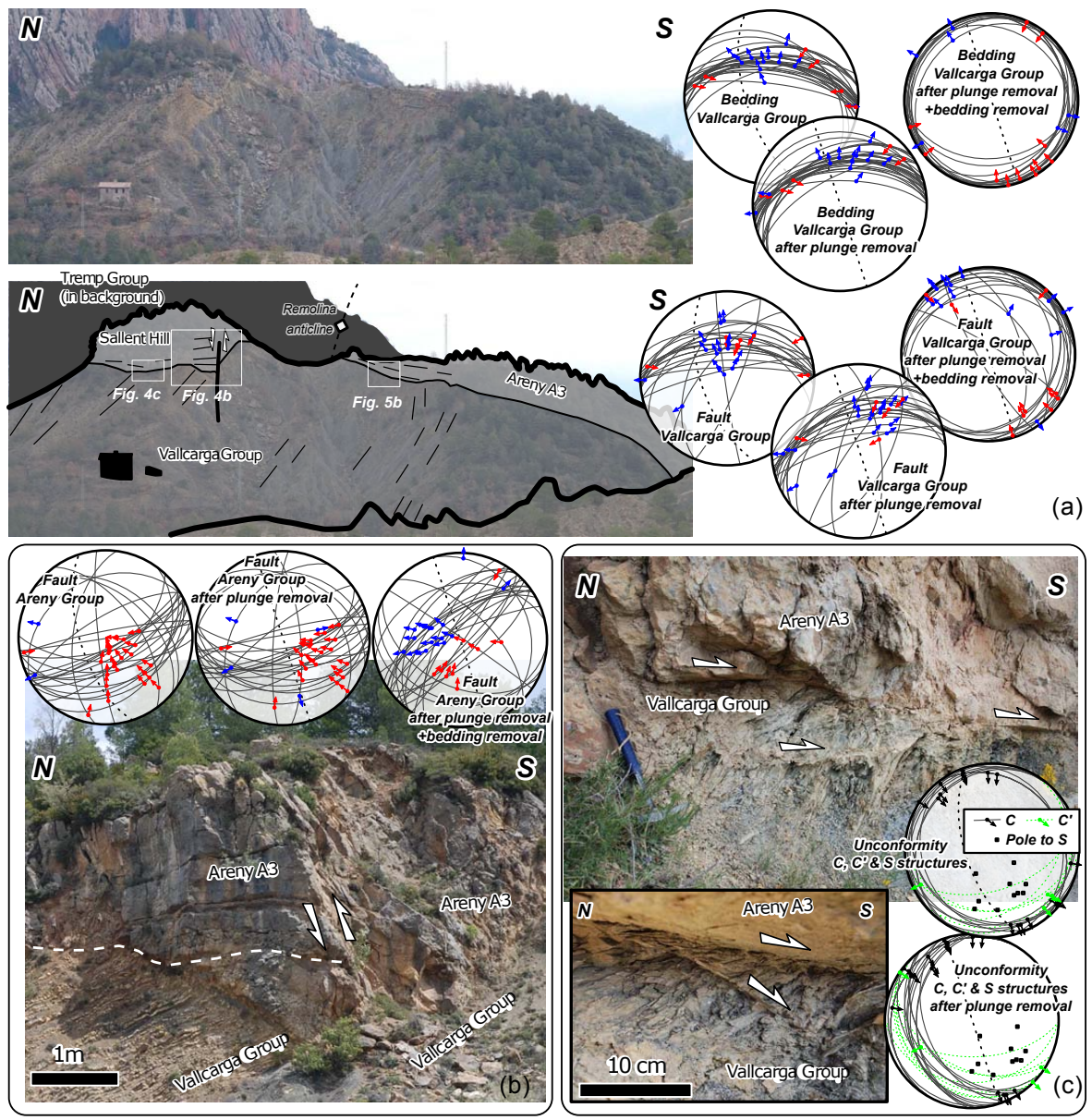

Figure 4. Macro- and meso-structures of the Remolina anticline. (a) Panoramic view and line-drawing of the Remolina anticline (with insets showing the location of (b) and (c), and Fig. 5b), with stereoplots of faults and bedding measured in the Vallcarga Group. (b) Detail of a south-dipping reverse fault with sub-horizontal carbonates of the Areny Group on top of overturned strata of the Vallcarga Group in its footwall. Stereoplots show fault data in the Areny carbonates. (c) Details of the unconformity, with S-C-C' illustrated and plotted.

of Fig. 4a, most of slickenlines display top-to-N normal kinematics, whereas a few are characterised by strike-slip (both left and right lateral) or reverse kinematics. The slickenlines displaying strike-slip and reverse kinematics postdate the top-to-N normal ones. Faults oblique to bedding have also been found in the Vallcarga Group in this area (Fig. 4a). The faults are at low angle with the bedding surface and display normal and, subordinately, reverse kinematics. After bedding dip removal, both bedding-parallel slip surfaces and beddingoblique faults show a top-to-NW slip sense. As mentioned above, strata of the rudist-bearing A3 sequence are shallow dipping (Fig. 4a-b) and the unconformity between the Areny and the Vallcarga groups is also sub-horizontal. The unconformity is affected by a pervasive shear fabric (Fig. 4c), with $\mathrm{S}, \mathrm{C}$ and $\mathrm{C}^{\prime}$ structures providing a top-to-SSE shear sense. In addition, the sheared unconformity is cross-cut by SSEdipping and NNW-verging reverse faults (Fig. 4b).

\subsection{Southern limb}

On the southern limb of the Remolina anticline, strata of the Areny Group are overturned to steeply south dipping (Fig. 5a). These strata are still unconformable on top of the overturned strata of the Vallcarga Group, but the unconformity angle between the two groups becomes significantly reduced to about $20^{\circ}$. The unconformity preserves its stratigraphic origin and, as opposed to the northern and central limbs of the Sant Maximí syncline, no appreciable evidence of shear occurs (Fig. 5b). Instead, striae along the bedding surfaces of the Areny Group are observed (Fig. 5c). These striae indicate normal top-to-NNW and reverse top-toNNE movements along north-dipping overturned and steeply south-dipping strata respectively (Fig. 5c). In both cases, striae lie along the bedding surfaces at the intersection between bedding and the plunge-normal plane (Fig. 5c). Faults at a low angle to bedding have the same behaviour as the bedding: south- and north-dipping faults are reverse and normal 


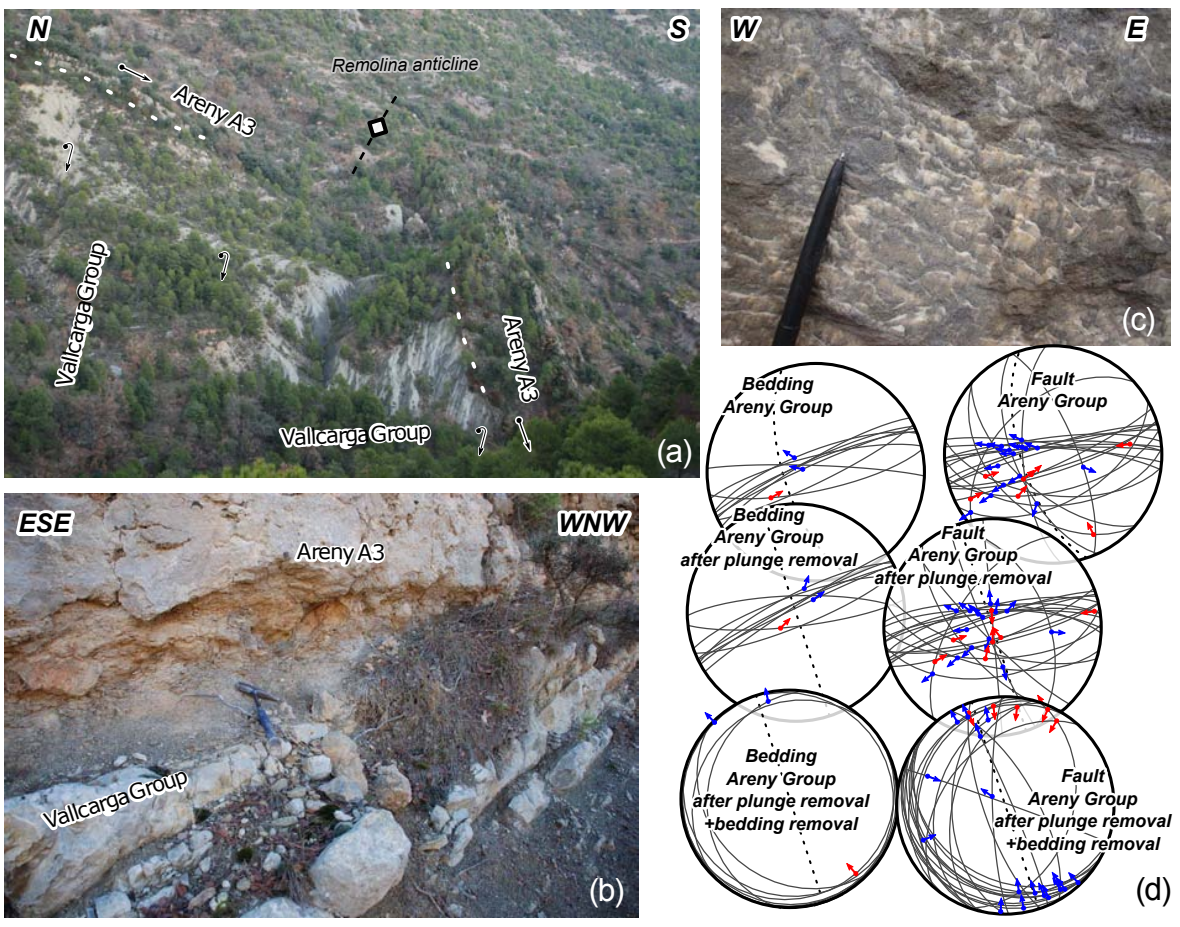

Figure 5. (a) Panoramic view of the hinge zone of the Remolina anticline, visible in the Areny strata that are on top of constantly dipping strata of the Vallcarga Group. (b) Detail of the unconformity between the Areny and Vallcarga groups at the southern limb of the anticline, where no evidence of shear occurs. (c) Detail of slickenlines along a near-vertical bedding surface of the Areny strata, providing a top-tonorth slip sense for the upper bed. (d) Stereoplots of bedding surfaces and faults collected in the Areny Group strata of the southern limb of the Remolina anticline.

respectively with slickenlines lying at the intersection between the fault and the plunge-normal plane (Fig. 5c). Once bedding dip is restored to the horizontal, a top-to-NNW slip sense is exhibited by both faults and bedding-parallel slip surfaces.

\subsection{Structural summary}

The deformation structures observed along and around the unconformity separating the upper syn-folding strata of the Areny Group from the underlying multilayered limestones and marls of the pre-folding Vallcarga Group can be summarised as follows:

In the Vallcarga Group, many of the E-W-striking bedding surfaces of near-vertical to overturned strata have been reactivated as slip surfaces. Most of these bed-parallel slip surfaces exhibit dip-slip kinematics, with only a few beds showing strike-slip movements. After removing the plunge of the structure and then restoring the local bedding to the horizontal, most of the slickenlines measured along the bedding surfaces provide a slip sense ranging from top-to-NW to top-to-N, with an average top-to-NNW movement. Faults are roughly E-W to WSW-ENE striking and show very low cut-off angles to bedding. After removing the fold plunge and the bedding dip, these faults provide the same top-to-
NNW slip sense as the bedding-parallel slickenlines. Some faults, which are presently steeply dipping to near vertical, have cut-off angles ranging from 20 to $40^{\circ}$, and after removing plunge and bedding dip, they show normal kinematics. Still, the slip sense provided by them after bedding dip removal is top to NNW. This fault pattern and the illustrated kinematics of bedding surfaces are observed all across the studied thrust-related fold profile, i.e. in the northern, central and southern limbs.

The syn-folding unconformity is characterised by an intense $\mathrm{S}-\mathrm{C}$ fabric (showing also some $\mathrm{C}^{\prime}$ structures) in the northern limb and in the sub-horizontal central limb. In both cases, slip direction is roughly NNW-SSE, although some strike-slip movements are occasionally observed. However, the slip sense is opposite in the two limbs, being top to NNW in the northern limb (i.e. where the sheared unconformity strikes about $\mathrm{E}-\mathrm{W}$ and has a near-vertical attitude) and top to SSE in the central limb (i.e. where the sheared unconformity is offset by the steeply dipping to near-vertical faults surging from the underlying Vallcarga Group). Further to the south, in the southern limb of the Remolina anticline, the unconformity shows little evidence of deformation.

Strata of the Areny Group exposed at the northern limb of the San Maximí syncline are affected by an intense cleavage at high angle to bedding. The cleavage-bedding angle is 
not exactly $90^{\circ}$, however, indicating the occurrence of a topto-NNW bedding-parallel slip component. Slickenlines are observed along the bedding surfaces of the near-vertical to overturned strata of the Areny Group exposed at the southern limb of the Remolina anticline. In this area, some faults at very low angle to bedding occur. For both faults and bedding surfaces, the slip sense measured after removing the plunge and the dip of the bedding is roughly top to NNW.

\section{Chronology of deformation stages}

The syn-folding strata of the Areny Group exposed at the forelimb of the Sant Corneli-Bóixols anticline unconformably overlie the north-dipping overturned strata of the pre-folding Vallcarga Group. The unconformity between both groups is clearly a syn-folding feature. Its unconformity angle varies across the studied area, and in addition, its surface shows unequivocal evidence of strong shearing, with an average NNW-SSE-oriented shear direction. Such a shear direction is parallel to the slip directions measured along both faults and bedding surfaces of the Vallcarga and Areny groups. However, the NNW-SSE direction is not perpendicular to the average strike of the hosting anticline, although the local fold axis in the study area is WSW-ENE striking (Fig. 1a). This structural relationship reaffirms that the E-W-striking Sant Corneli-Bóixols anticline has developed under an oblique convergence setting where the shortening direction was NNW-SSE (Tavani et al., 2011). In this sense, the observed meso-structures are interpreted as developed during the growth of the Sant Corneli-Bóixols anticline, and they cannot be attributed to a subsequent tectonic event. The fact that these structures occur in syn-folding strata also rules out a pre-folding origin. In agreement with this, the observed opposite shear senses along the unconformity surface to the north and to the south of the San Maximí syncline axial surface have a syn-folding origin. As illustrated in the next section, these opposite senses of slip can be used to unravel the kinematic evolution of the unconformity, the unconformity angle itself and therefore that of the Sant CorneliBóixols anticline.

\section{Modelling the folding of the angular unconformity}

The existence of the Sant Maximí syncline and the Remolina anticline in syn-folding strata, with their axial planes being parallel to bedding in the pre-folding units, is a challenging geological feature. Neither shortening perpendicular to bedding of the pre-folding units nor inhomogeneous flexural slip can be invoked to explain their existence. In the first case, pervasive strain, indicating a remarkable amount of beddingperpendicular shortening, should be found in the strata of the pre-folding Vallcarga Group, which is not observed. In the second case, localised layer-parallel slip should be observed, but is also not observed. There are no remarkable lithologic changes in the pre-folding Vallcarga Group that could justify an inhomogeneous (i.e. discrete) flexural slip. In fact, significant bed-parallel slip is found distributed through the Vallcarga Group multilayer. In agreement with this, the existence of the Sant Maximí syncline and the Remolina anticline can be better explained in the framework of flexural folding of an angular unconformable sequence, which included different initial unconformity angles across the structure. Guidelines about flexural folding of angular unconformable sequences were firstly given by Alonso (1989). These include the progressive variation of the unconformity angle during tilting of pre-unconformity layers, synchronous with progressive slipping along the unconformity surface (Alonso, 1989). Figure 6a illustrates the folding of an unconformable sequence using a kink-band template with synclinal geometry. The position of six points undergoing folding is illustrated. The points $\mathrm{P}_{0}$ and $\mathrm{P}_{1}$ are fixed and inactive, i.e. they do not move during folding and the rock does not pass through them. The point $P_{1}$ is the origin of our reference system. The point $P_{2}$ is located at the intersection between the axial surface and the unconformity and, as the axial surface moves during folding, this point is an active point that migrates through the rock. The remaining points are mobile but inactive material points, which are attached to the rock. In detail, the points $\mathrm{P}_{3}$ and $\mathrm{P}_{5}$ are attached to the base of the post-unconformity unit, while the point $\mathrm{P}_{4}$ is immediately below the unconformity, and it is attached to the layer corresponding to the stratigraphic elevation of the point $P_{0}$. The simple kink-band construction is used to quantify how the unconformity angle and the amount of slip along the unconformity are modified during folding, where $D_{0}$ is the initial dip of layers, $U_{0}$ the initial unconformity angle, $H_{0}$ the stratigraphic elevation of the unconformity and $L_{0}$ the distance from the origin of an arbitrarily placed pin line (note that the $L_{0}$ parameter will disappear from the final equations used here). The $X$ and $Y$ coordinates of the six key points and the length of the segments joining them can be expressed as a function of $L_{0}, H_{0}, U_{0}, D_{0}$ and $D$, as provided in Fig. 6b. In particular, the length of the segment joining points $\mathrm{P}_{5}$ and $\mathrm{P}_{4}$ provides the amount of slip $(\Delta S$, considered positive when it is top to hinterland), while points $\mathrm{P}_{3}$ and $\mathrm{P}_{4}$ allow calculation of the unconformity angle $(U)$.

As folding takes place, the unconformity angle increases and the sense of slip along the unconformity is initially top to hinterland, i.e. in the same sense as the flexural slip along the pre-unconformity layers. When the pre-unconformity strata become overturned, the unconformity angle continues to increase and the flexural slip in the pre-unconformity layers continues to be top to hinterland; instead, the sense of slip along the unconformity flips and becomes top to foreland. Close to the leading syncline, i.e. along the $\mathrm{P}_{2} \mathrm{P}_{3}$ segment, the sense of the incremental slip is top to hinterland, whereas along the $\mathrm{P}_{3} \mathrm{P}_{4}$ segment it becomes to top to foreland, despite the cumulative slip may continue to be top to hinterland. 

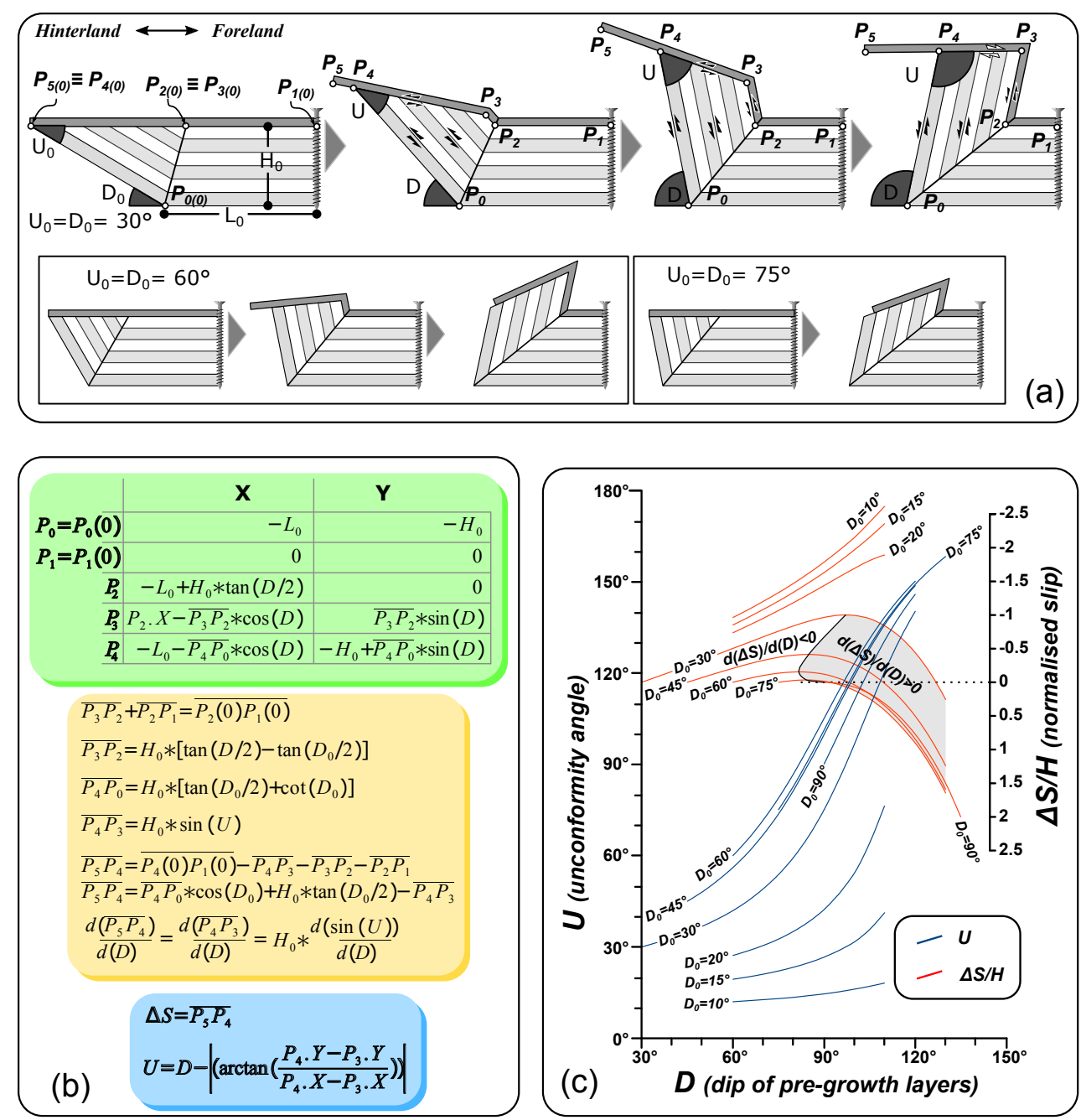

Figure 6. (a) Evolving angular relationships between unconformable sequences during flexural folding in the inner limb of a syncline, with incremental slip senses along pre-unconformity layers and along the unconformity indicated for different initial unconformity angles. The position of six points undergoing folding is illustrated, as well as the dip of pre-unconformity layers $(D)$ and of the unconformity angle $(U)$, which is the angle between the unconformity and the underlying layers. (b) $X$ and $Y$ coordinates of the six points of (a), with length of segments, and derived amount of slip along the unconformity $(\Delta S)$ and unconformity angle $(U)$. (c) Graphical solution of equations in (b). Blue lines relate the unconformity angle $(U)$ to the dip of pre-growth strata $(D)$ for different initial unconformity angles $\left(U_{0}\right)$. Red lines relates the normalised slip along the unconformity in the inner portion (i.e. $\Delta \mathrm{S}=\mathrm{P}_{4} \mathrm{P}_{5}$ segment divided $H$ ) to $D$ for different initial unconformity angles $\left(U_{0}\right)$. Notice that the $y$ axis for red lines is on the right and that positive and negative values are flipped. The lines indicate the cumulative slip along the unconformity, while the grey area bordered by the black line indicates the area where the incremental slip is negative.

The relationship between $U, U_{0}$ and $D$ derived in Fig. $6 \mathrm{~b}$ is graphed in Fig. 6c. The relationships between $U$ and $D$ (blue lines in the figure) for different $U_{0}$ values indicate that

1. it is possible to develop overturned pre-folding strata and a nearly sub-horizontal unconformity, as observed in the central limb of our study area, (i.e. the unconformity angle is roughly equal to the dip of the preunconformity layer) for a wide range of initial unconformity angles (from 30 to $90^{\circ}$ ).
2. in order to obtain an unconformity angle of less than $20^{\circ}$ where the pre-unconformity strata are near vertical, as observed in the northern and southern limbs of the study area, the initial unconformity angle cannot exceed $10-15^{\circ}$.

The predicted amount and sense of slip (normalised to $H_{0}$ ) at different tilting stages (i.e. for different $D$ ) and for different initial unconformity angles (i.e. $U_{0}$ ) are plotted in red in Fig. 6c, where positive and negative values indicate topto-hinterland and top-to-foreland slip respectively. For small 
initial unconformity angles, the unconformity angle and the cumulative top-to-hinterland slip along the unconformity increase during folding. This occurs until the dip of pre-growth strata attains a near-vertical attitude. From this point, further folding would imply overturning of strata and the decrease of the cumulative top-to-hinterland slip, which eventually becomes negative (i.e. top-to-foreland sense), while the unconformity angle $U$ exceeds $90^{\circ}$. Where the initial unconformity angle is close to $90^{\circ}$, progressive folding would imply a short period of top-to-foreland slipping along the unconformity, followed by top-to-hinterland slipping when strata become nearly vertical to overturned. At this point it is important to remark that the progressive and incremental slip senses do not coincide. The $D$ value at which the cumulative slip passes from top-to-hinterland to top-to-foreland largely depends on the initial unconformity angle $U_{0}$. Conversely, for an initial unconformity angle $U_{0}$ between 45 and $90^{\circ}$, the incremental slip changes its sign for values of $D$ ranging from 80 to $90^{\circ}$, almost regardless of $U_{0}$ value (the regions where the incremental slip has opposite directions are in white and grey in Fig. 6c).

The absence of any kinematic indicator of top-tohinterland slip in the central limb of the study area indicates that the initial unconformity angle had to be high at that position, and if any, the initial stage of top-to-hinterland slip was negligible. This can be achieved when the initial unconformity angle is at least $70-75^{\circ}$. This represents a key argument for unravelling the deformation sequence as structures postdating the top-to-foreland slipping have to be interpreted as developed synchronously with layer tilting, and in particular, as developed at least after layers have become near vertical. The top-to-hinterland slip sense and the small unconformity angle observed in the northern limb, instead, point out a small initial unconformity angle.

It is worth noting that the position of the axial surface is determined by the position of $\mathrm{P}_{0}$, and thus by the value of $L_{0}$ and $H_{0}$. These two parameters do not influence the value of the unconformity angle. Instead, the amount of slip is directly proportional to the value of $H_{0}$. However, we are interested in the sign of the slip, which is independent of $H_{0}$. In agreement, provided results are unrelated to the position of the axial surface, and thus of $\mathrm{P}_{0}$, which can be arbitrarily set everywhere below the unconformity.

Two cautionary notes must be added for these conclusions. (1) They are based on a purely geometric model, in which both bed thickness and line length are preserved during folding. However, and despite the occurrence of local penetrative strain at some places (Fig. 2d), based on the field observations reported here and in Tavani et al. (2011), pressure solution cleavage is an extremely localised phenomenon in this anticline, and deformation structures pointing out foldingrelated bed thickness variations do not occur. In agreement, and despite the intrinsic simplification of any geometric model, information provided by the model of Fig. 6 can be applied to our case study. (2) The model described above al-

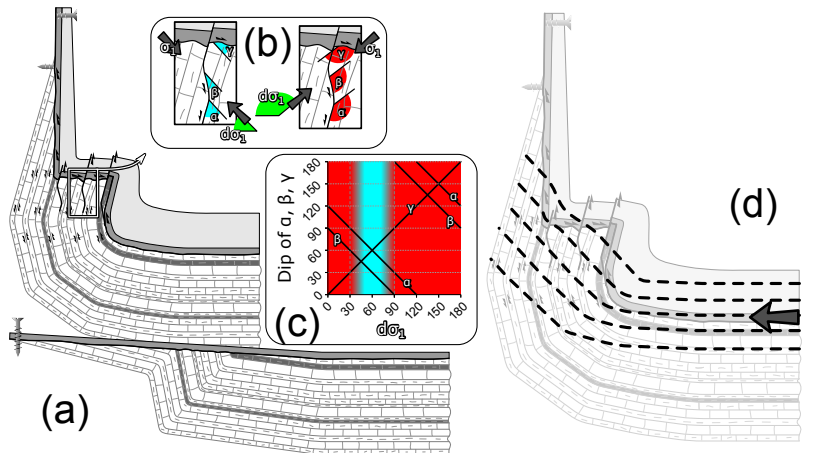

Figure 7. (a) Scheme showing the present-day geometry of the frontal limb of the Sant Corneli-Bóixols anticline (upper part), the geometry of the unconformity, and the pre- and syn-folding strata before folding (lower part). (b) Details showing the structural assemblages observed at the Remolina anticline, with two alternative configurations for the maximum stress orientation. The maximum stress forms the following clockwise angles: $d \sigma_{1}$ with the horizontal, $\gamma$ with the unconformity, $\alpha$ with the bedding-parallel steps of flexural-slip faults in the Vallcarga Group, and $\beta$ with the oblique to bedding strands of the flexural-slip fault in the Vallcarga Group. Red and cyan colours indicate angles not compatible and compatible with the observed slip pattern respectively. (c) Relationships between $d \sigma_{1}$ and $\alpha, \beta$ and $\gamma$, with the red area indicating the orientation of the maximum stress not compatible with the slip pattern observed at the Remolina anticline. (d) Inferred maximum stress trajectories during the late stages of folding.

lows the reconstruction of the initial, pre-unconformity configuration of the Vallcarga Group units. However, like in all the retro-deformed models produced by cross-section balancing, we have no direct access to the "real" initial configuration. We cannot thus discuss the discrepancy between the model and the reality. We can merely observe that the assumptions of the model, i.e. line-length and bed thickness preservation and flexural slipping, are largely consistent with field observations.

\section{Discussion}

\subsection{Relative timing between slipping and layer tilting}

Strata of the Vallcarga Group exposed at the forelimb of the Sant Corneli-Bóixols anticline display a rather constant attitude. However, according to the model described in Fig. 6, slip senses and angles of the unconformity on top of these strata indicate that the pre-unconformity layers (i.e. the Vallcarga Group) were not homoclinally dipping when the Areny Group was unconformably deposited on top them. The scheme of Fig. 7a illustrates the present-day simplified geometry of the studied structure, together with the balanced (i.e. line length is preserved; Dahlstrom, 1969; Brandes and Tanner, 2014) reconstruction at a time immediately after the unconformity development. The reconstructed dip 
of pre-unconformity layers in the three limbs is obtained according to what is illustrated in Sect. 5. As previously mentioned, the top-to-foreland shearing along the unconformity of the central limb has to be interpreted as occurring when strata of the Vallcarga Group attained a near-vertical to overturned attitude. Conversely, the absence of any evidence of top-to-hinterland shearing along the unconformity surface at the central limb suggests that such an unconformity had to be developed when the layers of the Vallcarga Group were steeply dipping. In agreement with this, the north-dipping faults offsetting the sheared unconformity have to be regarded as syn-folding structures developed when strata of the Vallcarga Group were overturned. These 10 to $30 \mathrm{~m}$ spaced faults mostly consist of bedding-parallel segments (Figs. 4a and 5d), with some strands showing cut-off angles between 20 and $40^{\circ}$ (see stereoplots of Fig. 3b-c), and are interpreted as flexural-slip faults, like those offsetting the topographic surface of growth folds (e.g. Burbank and Anderson, 2011; Gutiérrez et al., 2014; Li et al., 2015). These faults are therefore late-stage flexural-slip features and, as detailed in the next subsection, cannot be compatible with a sub-horizontal maximum stress.

\subsection{Maximum stress orientation}

The studied natural stratigraphic units includes centimetre to metre thick strata of limestones, marls, sandstones and conglomerates exposed across a $500 \mathrm{~m}$ wide area (Fig. 1). The large number of strata involved in the deformation, coupled with their high compositional variability, prevent the collection of a representative dataset of friction and cohesion of both layers and interlayers. It thus makes it impossible to carry out a quantitative dynamic (i.e. stress) reconstruction. However, many stress configurations can be easily discarded due to their kinematic inconsistency with the observed shearing pattern. In particular, we consider that the maximum palaeo-stress lies on the plane oriented perpendicular to the fault and/or flexural-slip plane and containing the slip direction, and it forms an obtuse angle with the slip sense (e.g. Etchecopar et al., 1981). The following observations can thus restrict the range of possible solution and the sources of stress during folding: (1) if we consider faults and strata in their present orientation and after plunge and bedding dip removal, the top-to-foreland layer-parallel slipping and the south-verging reverse faulting are rare features in the northern limb of the San Maximí syncline, which is located at a distance of less than $100 \mathrm{~m}$ from the Bóixols thrust. The scarcity of these structures, and the occurrence of flexural-slip surfaces forming a low angle with the thrust and having an opposite slip sense (i.e. normal kinematics), indicates the limited role of faulting-related stress, sourced from the process zone (e.g. Cowie and Scholz, 1992) of the upward propagating Bóixols thrust, in controlling the pattern of syn-folding slipping. This is contrary to what has instead been documented in other thrust-related anticlines (e.g. Bel- lahsen et al., 2006). (2) The top-to-hinterland (i.e. top to crest of the Sant Corneli-Bóixols anticline) layer-parallel slipping observed along the bedding surfaces of the Vallcarga Group for all three limbs has to be regarded as syn-folding. With the exception of a few bedding-oblique strands of flexuralslip faults, no significant evidence of strata thinning and/or thickening has been observed in the Vallcarga Group. This points out that folding has been almost entirely produced by layer-parallel slipping with bed-thickness preservation until late stage flexural-slip faulting took place (e.g. Donath and Parker, 1964). (3) Deformation structures such as the nearly layer-parallel shortening-related cleavage measured in the silty levels of the Areny Group along the axial zone of the San Maximí syncline indicate a maximum stress oriented at a low angle to bedding (Fig. 2d). (4) The fourth key observation concerns the steeply dipping faults, with high cut-off angles, cutting and displacing the unconformity. These faults include steps with cut-off angles of about $30^{\circ}$ and steps parallel to the overturned bedding surfaces. Under the assumption that late-stage flexural-slip faulting caused the arrest of shearing along the unconformity, a range of possible maximum stress orientation during the transition from top-toforeland shearing along the unconformity to the late-stage flexural-slip faulting can be defined for the central limb, as shown in Fig. 7b. The angle between the maximum stress and the bedding-parallel steps of flexural-slip faults in the Vallcarga Group is $\alpha$ and the angle between the maximum stress and the flexural-slip fault strands oblique to bedding in the Vallcarga Group is $\beta$, whereas the angle between the maximum stress and the unconformity is $\gamma$. These three angles must be comprised of a value between 0 and $90^{\circ}$ to produce the observed slip pattern and for it to be kinematically compatible. When using the average dip of the unconformity (i.e. $0^{\circ}$ ) and the dip of the Vallcarga Group strata in the central limb (i.e. $60^{\circ}$ overturned), a maximum stress dip (labelled $d \sigma_{1}$ in Fig. 7 b) ranging from 30 to $90^{\circ}$ is obtained.

At this stage, one may argue that the maximum stress was inclined only during the latest stage of folding, when prefolding strata were overturned, while the maximum stress was sub-horizontal during most of the folding process. Such a scenario, in which the reorientation of the maximum stress is a discontinuous process, contrasts with the fact that in order to produce slipping along bedding surfaces, the maximum stress should have been south dipping, not only when strata were $60^{\circ}$ overturned. In fact, dip-slip slipping along upright layers also requires the maximum stress to be south dipping, and such a stress configuration can also be extrapolated for steeply (e.g. $>75^{\circ}$ ) south-dipping strata. In agreement, we consider that the stress rotation was not a discontinuous process, but instead it has continuously operated during folding.

As documented in Tavani et al. (2011), the layer-parallel shortening pattern in the Sant Corneli-Bóixols anticline indicates a sub-horizontal maximum stress before folding and during the early stages of folding. As evidenced by data 
presented here, the stress was in a configuration not allowing faulting in the Vallcarga Group layers during almost the entire folding process. Such stress configuration was able to produce slipping along the bedding surfaces and along the unconformity though, with faulting in the Vallcarga and Areny Groups being almost negligible. Apart from those structures associated with the layer-parallel slipping, the few additional deformation structures point out a maximum stress oriented at low angle to bedding. During the late stage of folding, when the unconformity angle exceeded $120-130^{\circ}$, the maximum stress was south dipping, with an angle higher than $30^{\circ}$. Then, the stress attained a state allowing faulting within the Vallcarga Group layers. Contextually, bedding surfaces of the Vallcarga Group continued to be sheared, while shearing along the unconformity in the central limb arrested.

\subsection{Flexural slipping and stress reorientation}

The information discussed above argues for a syn-folding maximum stress rotation and/or reorientation within the growing anticline, from sub-horizontal early-folding layerparallel shortening in Tavani et al. (2011) to south-dipping maximum stress in overturned strata documented here. As schematically illustrated in Fig. 7d, we infer that the subhorizontal maximum stress applied to the leading syncline of the growing Sant Corneli-Bóixols anticline (i.e. the remotely applied stress has an Andersonian compressive configuration; Anderson, 1951) progressively rotated as it was transmitted across folding rock volumes affected by widespread flexural slipping. In agreement with the hypothesis outlined in the introduction, this process of stress deflection is interpreted here as associable with the flexural-slipping mechanism. In fact, as largely documented, slipping along lowfriction faults produces the perturbation of the remotely applied stress field (e.g. Pollard and Segall, 1987; Soliva et al., 2010) and, in particular, reduction of the fault-parallel shear stress component causes the orientation of principal stress to locally rotate towards a fault-parallel direction. Consistently with this, the coupling between flexural slip and maximum stress reorientation documented in other structures has been attributed to the fact that slipping along closely spaced lowfriction bedding surface imposes the maximum stress to orient at low angle to the slipping bedding surface over a wide area (i.e. the flexural-slip folded area), as mentioned in the introduction (Wiltschko et al., 1985; Ohlmacher and Aydin, 1997; Tavani et al., 2012). This concept fully applies to the data presented in this work until the strata attain a strongly overturned attitude. The close link between flexural slipping and stress reorientation also implies that the amount of deflection of the maximum compressive stress scales with the amount of flexural slipping. Accordingly, if the growth of an anticline occurs in a discontinuous fashion, the orientation of maximum compressive stress is expected to rotate repeatedly during the repeated pulses of flexural slip. In the case documented here, the absence of any indicators of a sub- horizontal maximum stress could be related to the fact that Andersonian stress configuration would characterise stages in which the maximum stress is low and in a subcritical state, not allowing faulting and folding. Repeated pulses of maximum stress increase would instead cause the progressive slipping of bedding surfaces, with consequent maximum stress deflection.

\section{Conclusions}

This work has allowed the determination of the threshold dip value at which flexural slipping can be operative and of sufficient magnitude to deflect the maximum principal stress direction from its regional orientation. In the studied area, flexural slipping has been an active process, discontinuous at the local scale, but sufficiently dense in time and space at the scale of the growing fold for local stress deflection to occur. The mechanism operated up to $120^{\circ}$ of dip (i.e. overturned bedding) and caused the maximum stress to progressively reorient at low angle to bedding until strata attained an overturned attitude.

Data availability. Raw data of faults, bedding and other mesostructures graphed in the stereoplots can be found in the Supplement as a CSV file.

\section{The Supplement related to this article is available online at doi:10.5194/se-8-405-2017-supplement.}

Acknowledgements. The authors sincerely thank the reviewers, Ryan Shackleton, Richard Lisle, Juliet Crider, Hugo Ortner, and the editors for their constructive comments and suggestions. The cross sections presented in this work were constructed using 3-D Move software. This work is a contribution of the following research institutions: DISTAR from the Università degli Studi di Napoli "Federico II", the Institut de Recerca Geomodels and the Geodinàmica i Analisi de Conques research group (2014SGR467SGR) from the Agència de Gestió d'Ajuts Universitaris i de Recerca (AGAUR) and the Secretaria d'Universitats i Recerca del Departament d'Economia i Coneixement de la Generalitat de Catalunya.

Edited by: B. Grasemann

Reviewed by: R. Lisle and H. Ortner

Competing interests. The authors declare that they have no conflict of interest.

\section{References}

Alonso, J. L.: Fold reactivation involving angular unconformable sequences: theoretical analysis and natural examples from the 
Cantabrian Zone (Northwest Spain), Tectonophysics, 170, 5777, 1989.

Anderson, E. M.: The Dynamics of Faulting, Oliver and Boyd, Edinburgh, 1951.

Arbués, P., Pi, E., and Berástegui, X.: Relaciones entre la evolución sedimentaria del Grupo de Arén y el cabalgamiento de Bóixols (Campaniense terminal-Maastrichtiense del Pirineo meridionalcentral), Geogaceta, 20, 446-449, 1996.

Balsamo, F., Clemenzi, L., Storti, F., Mozafari, M., Solum, J., Swennen, R., Taberner, C., and Tueckmantel, C.: Anatomy and paleofluid evolution of laterally restricted extensional fault zones in the Jabal Qusaybah anticline, Salakh arch, Oman, Geol. Soc. Am. Bull., 128, 957-972, 2016.

Beamud, E., Muñoz, J. A., Fitzgeral, P. G., Baldwin, S. L., Garcés, M., Cabrera, L., and Metcalf, J. R.: Magnetostratigraphy and detrital apatite fission track thermochronology in syntectonic conglomerates: constraints on the exhumation of the South-Central Pyrenees, Basin Res., 23, 309-331, 2011.

Belayneh, M. and Cosgrove, J. W.: Fracture-pattern variations around a major fold and their implications regarding fracture prediction using limited data: an example from the Bristol Channel Basin, Geological Society, London, Special Publications, 231, 89-102, 2004.

Bellahsen, N., Fiore, P. E., and Pollard, D. D.: From spatial variation of fracture patterns to fold kinematics: A geomechanical approach, Geophys. Res. Lett., 33, L02301, doi:10.1029/2005GL024189, 2006.

Berástegui, X., García-Senz, J. M., and Losantos, M.: Tectosedimentary evolution of the Organya extensional basin (central south Pyrenean unit, Spain) during the Lower Cretaceous, Bulletin de la Societe Geologique de France, 8, 251-264, 1990.

Bond, R. M. G. and McClay, K. R.: Inversion of a Lower Cretaceous extensional basin, south central Pyrenees, Spain, Geological Society, London, Special Publications, 88, 415-431, 1995.

Brandes, C. and Tanner, D. C.: Fault-related folding: A review of kinematic models and their application, Earth-Sci. Rev., 138, 352-370, 2014.

Burbank, D., Meigs, A., and Brozović, N.: Interactions of growing folds and coeval depositional systems, Basin Res., 8, 199-223, 1996.

Burbank, D. W. and Anderson, R. S.: Tectonic geomorphology, Blackwell, Oxford, 2011.

Callot, J. P., Robion, P., Sassi, W., Guiton, M. L. E., Faure, J.-L., Daniel, J. M., Mengus, J.-M., and Schmitz, J.: Magnetic characterisation of folded aeolian sandstones: Interpretation of magnetic fabrics in diamagnetic rocks, Tectonophysics, 495, 230$245,2010$.

Choukroune, P., Roure, F., and Pinet, B.: Main results of the ECORS Pyrenees profile, Tectonophysics, 173, 411-423, 1990.

Cowie, P. A. and Scholz, C. H.: Displacement-length scaling relationship for faults: data synthesis and discussion, J. Struct. Geol., 14, 1149-1156, 1992.

Cuevas, J. L.: Estratigrafía del "Garumniense" de la Conca de Tremp. Prepirineo de Lérida, Acta geológica hispánica, 27, 95108, 1992.

Dahlstrom, C. D. A.: Balanced cross sections, Can. J. Earth Sci., 6, 743-757, 1969.

Donath, F. A. and Parker, R. B.: Folds and folding, Geol. Soc. Am. Bull., 75, 45-62, 1964.
Engelder, T. and Geiser, P.: On the use of regional joint sets as trajectories of paleostress fields during the development of the Appalachian plateau, New York, J. Geophys. Res., 85, 6319-6341, 1980.

Erslev, E. A. and Mayborn, K. R.: Multiple geometries and modes of fault-propagation folding in the Canadian thrust belt, J. Struct. Geol., 19, 321-335, 1997.

Etchecopar, A., Vasseur, G., and Daignieres, M.: An inverse problem in microtectonics for the determination of stress tensors from fault striation analysis, J. Struct. Geol., 3, 51-65, 1981.

Fischer, M. P. and Wilkerson, M. S.: Predicting the orientation of joints from fold shape: results of pseudo-three-dimensional modeling and curvature analysis, Geology, 28, 15-18, 2000.

Ford, M., Williams, E. A., Artoni, A., Vergés, J., and Hardy, S.: Progressive evolution of a fault-related fold pair from growth strata geometries, Sant Llorenç de Morunys, SE Pyrenees, J. Struct. Geol., 19, 413-441, 1997.

Fowler, T. J.: Flexural-slip generated bedding-parallel veins from central Victoria, Australia, J. Struct. Geol., 18, 1399-1415, 1996.

García-Senz, J.: Cuencas extensivas del Cretácico Inferior en los Pirineos centrales. Formación y subsecuente inversión, PhD Thesis, 310 pp., Universitat de Barcelona, 2002.

Garrido, A.: Estudio geologico y relacion entre teclonica y sedimentacion del Secundario y Terciario de la vertiente meridional Pirenaica en su zona central, $\mathrm{PhD}$ Thesis, 395 pp., Universidad de Granada, 1973.

Gutiérrez, F., Carbonel, D., Kirkham, R. M., Guerrero, J., Lucha, P., and Matthews, V.: Can flexural-slip faults related to evaporite dissolution generate hazardous earthquakes? The case of the Grand Hogback monocline of west-central Colorado, Geol. Soc. Am. Bull., 126, 1481-1494, 2014.

Hancock, P. L.: Brittle microtectonics: principles and practice, J. Struct. Geol., 7, 437-457, 1985.

Lacombe, O.: Do fault slip data inversions actually yield "paleostresses" that can be compared with contemporary stresses? A critical discussion, C. R. Geosci., 344, 159-173, 2012.

Lanaja, J. M.: Contribución de la exploración petrolífera al conocimiento de la geología de España, 465 pp., IGME, Madrid, 1987.

Laubach, S. E.: Paleostress directions from the preferred orientation of closed microfractures (fluid-inclusion planes) in sandstone, East Texas basin, U.S.A., J. Struct. Geol., 11, 603-611, 1989.

Li, T., Chen, J., Thompson, J. A., Burbank, D. W., and Yang, X.: Active flexural-slip faulting: A study from the Pamir-Tian Shan convergent zone, NW China, J. Geophys. Res.-Sol. Ea., 120, 43594378, 2015.

Lisle, R. J.: Detection of zones of abnormal strains in structures using Gaussian curvature analysis, AAPG Bull., 78, 1811-1819, 1994.

Medwedeff, D. W.: Growth fault-bend folding at southeast Lost Hills, San Joaquin Valley, California, Bulletin of the American Association of Petroleum Geologists, 73, 54-67, 1989.

Mencos, J.: Metodologies de reconstrucció i modetització 3D d'estructures geològiques: anticlinal de Sant Corneli-Bóixols (Pirineus centrals), PhD Thesis, 277 pp., Universitat de Barcelona, 2011.

Mencos, J., Carrera, N., and Muñoz, J. A.: Influence of rift basin geometry on the subsequent postrift sedimentation and basin inversion: The Organyà Basin and the Bóixols thrust 
sheet (south central Pyrenees), Tectonics, 34, 1452-1474, doi:10.1002/2014TC003692, 2015.

Mitra, S.: Fault-propagation folds: geometry, kinematic evolution, and hydrocarbon traps, AAPG Bull., 74, 921-945, 1990.

Muñoz, J. A.: Evolution of a continental collision belt: ECORSPyrenees crustal balanced cross-section, in: Thrust tectonics, edited by: McClay, K. R., 235-246, Chapman \& Hall, London, 1992.

Muñoz, J. A.: The Pyrenees, in: The Geology of Spain, edited by: Gibbons, W. and Moreno, T., 370-385, Geological Society, London, 2002

Muñoz, J. A., Carrera, N., Mencos, J., Beamud, B., Perea, H., Arbués, P., Rivas, G., Bausà J., and Garcia-Senz, J.: Cartografia geològica del substrat prequaternari, Map 252-2-2 (66-22), Aramunt scale $1: 25000$, Institut Cartogràfic de Catalunya (ICC), Servei Geològic de Catalunya (IGC), Barcelona, 2010.

Nagtegaal, P. J. C.: Depositional history and clay minerals of the Upper Cretaceous basin in the South-Central Pyrenees, Spain, Leidse Geologische Mededelingen, 47, 251-275, 1972.

Nicol, A. and Nathan, S.: Folding and the formation of beddingparallel faults on the western limb of Grey Valley Syncline near Blackball, New Zealand, New Zeal. J. Geol. Geop., 44, 127-135, 2001.

Ohlmacher, G. C. and Aydin, A.: Mechanics of vein, fault and solution surface formation in the Appalachian Valley and Ridge, northeastern Tennessee, USA: implications for fault friction, state of stress and fluid pressure, J. Struct. Geol., 19, 927-944, 1997.

Poblet, J., Storti, F., McClay, K., and Muñoz, J. A.: Geometries of syntectonic sediments associated with single-layer detachment folds, J. Struct. Geol., 19, 369-381, 1997.

Pollard, D. D. and Segall, P.: Theoretical displacements and stresses near fractures in rock: with applications to faults, joints, veins, dikes, and solution surfaces, Fracture mechanics of rock, Academic Press, London, 1987.

Price, N. J. and Cosgrove, J. W.: Analysis of Geological Structures, Cambridge, New York, Cambridge University Press, 511 pp., ISBN 0521265819, 1990.

Ramsay, J. G.: Folding and Fracturing of Rocks, McGraw-Hill, New York, 1967.

Roma, M., Arbués, P., Granado, P., Gratacós, O., and Muñoz, J. A.: The Sallent growth strata: an example of complex fold amplification mechanisms interacting with deepwater to continental sedimentation (South-Central Pyrenees, Spain), Abstracts with Poster, T4b, Sedimentation and Tectonics, 28th IAS Meeting of Sedimentology, 2011.

Rosell, J.: Sobre la existencia de la discordancia precenomaniense en el Pirineo de la provincia de Lerida, Notas y Comunicaciones del Instituto Geológico y Minero de España, 72, 71-80, 1963.

Shackleton, J. R., Cooke, M. L., and Sussman, A. J.: Evidence for temporally changing mechanical stratigraphy and effects on joint-network architecture, Geology, 33, 101-104, 2005.

Shackleton, J. R., Cooke, M. L., Vergés, J., and Simó, T.: Temporal constraints on fracturing associated with fault-related folding at Sant Corneli anticline, Spanish Pyrenees, J. Struct. Geol., 33, 519, 2011.

Simó, A.: Carbonate platform depositional sequences, Upper Cretaceous, South Central Pyrenees (Spain), Tectonophysics, 129, 205-231, 1986.
Soliva, R., Maerten, F., Petit, J. P., and Auzias, V.: Field evidences for the role of static friction on fracture orientation in extensional relays along strike-slip faults: Comparison with photoelasticity and 3-D numerical modeling, J. Struct. Geol., 32, 1721-1731, 2010.

Suppe, J.: Geometry and kinematics of fault-bend folding, Am. J. Sci., 283, 684-721, 1983.

Suppe, J. and Medwedeff, D. A.: Geometry and kinematics of faultpropagation folding, Eclogae Geol. Helv., 83, 409-454, 1990.

Suppe, J., Chou, G. T., and Hook, S. C.: Rates of folding and faulting determined from growth strata, in: Thrust tectonics, edited by: McClay, K. R., 105-121, Chapman \& Hall, London, 1992.

Suppe, J., Sàbat, F., Muñoz, J. A., Poblet, J., Roca, E., and Vergés, J.: Bed-by-bed fold growth by kink-band migration: Sant Llorenç de Morunys, eastern Pyrenees, J. Struct. Geol., 19, 443-461, 1997.

Tanner, P. W.: The flexural-slip mechanism, J. Struct. Geol., 11, 635-655, 1989.

Tavani, S., Storti, F., Fernández, O., Muñoz, J. A., and Salvini, F.: 3-D deformation pattern analysis and evolution of the Anisclo anticline, southern Pyrenees, J. Struct. Geol., 28, 695-712, 2006.

Tavani, S., Mencos, J., Bausà, J., and Muñoz, J. A.: The fracture pattern of the Sant Corneli Bóixols oblique inversion anticline (Spanish Pyrenees), J. Struct. Geol., 33, 1662-1680, 2011.

Tavani, S., Storti, F., Bausà, J., and Muñoz, J. A.: Late thrusting extensional collapse at the mountain front of the northern Apennines (Italy), Tectonics, 31, TC4019, doi:10.1029/2011TC003059, 2012.

Tavani, S., Storti, F., Lacombe, O., Corradetti, A., Muñoz, J. A., and Mazzoli, S.: A review of deformation pattern templates in foreland basin systems and fold-and-thrust belts: Implications for the state of stress in the frontal regions of thrust wedges, EarthSci. Rev., 141, 82-104, 2015.

Teixell, A.: Crustal structure and orogenic material budget in the west central Pyrenees, Tectonics, 17, 395-406, 1998.

Tesei, T., Collettini, C., Vitic, C., and Barchi, M. R.: Fault architecture and deformation mechanisms in exhumed analogues of seismogenic carbonate-bearing thrusts, J. Struct. Geol., 55, 167$181,2013$.

Tugend, J., Manatschal, G., Kusznir, N. J., Masini, E., Mohn, G., and Thinon, I.: Formation and deformation of hyperextended rift systems: Insights from rift domain mapping in the Bay of BiscayPyrenees, Tectonics, 33, 1239-1276, 2014.

Vergés, J., Fernàndez, M., and Martínez, A.: The Pyrenean orogen: pre-, syn-, and post-collisional evolution, Journal of the Virtual Explorer, 8, 57-76, 2002.

Vitale, S., Zaghloul, M. N., Tramparulo, F. D. A, and El Ouaragli, B.: Deformation characterization of a regional thrust zone in the northernRif (Chefchaouen, Morocco), J. Geodyn., 77, 22-38, 2014.

Wiltschko, D. V., Medwedeff, D. A., and Millson, H. E.: Distribution and mechanisms of strain within rocks on the northwest ramp of Pine Mountain block, southern Appalachian foreland: a field test of theory, Geol. Soc. Am. Bull., 96, 426-435, 1985.

Zapata, T. R. and Allmendinger, R. W.: Growth stratal records of instantaneous and progressive limb rotation in the Precordillera thrust belt and Bermejo basin, Argentina, Tectonics, 15, 10651083, 1996. 